\title{
The Independence of Constitutional Judges: \\ The Case of Jordan
}

\section{Sufian Obeidat}

\begin{abstract}
This study aims to demonstrate why the independence of constitutional judges in Jordan is undermined. The study describes the system of government in constitutional and political contexts; the powers of the unaccountable monarch, undermined branches of power and compromised political parties. A backdrop of the constitutional review history is followed by a detailed description of the constitutional and legal organization of the Jordanian Constitutional Court, including the mode of appointment of Constitutional Court members, the absence of a proper nomination process, and the restricted accessibility to the Court for the public and the Court itself. The study concludes with a discussion of the feasibility of reforming the Constitutional Court in a flawed political system where the unaccountable king, who has the sole power to select, appoint and remove the judges of the Constitutional Court by virtue of the Constitution. It argues for a substantial role for all the political actors in the appointment of members of the Constitutional Court in order to achieve a significant advancement towards constitutionalism.
\end{abstract}

\section{Introduction}

The selection and appointment of a member of the Constitutional Court in Jordan is not a complex procedure. On the contrary, it is very basic, though controversial. By virtue of the Constitution of Jordan of 1952 (the "Constitution"), ${ }^{1}$ the King has the sole power to appoint the chairperson and judges of the Constitutional Court without sharing such power with any other entity in the Jordanian system of government.

Historically, the Jordanian constitutional review used to be a diffused system carried out by courts of general jurisdiction. In 2011, a popular

1 The Constitution of The Hashemite Kingdom of Jordan of 1952. Official Gazette 1093, 8 January 1952: 3 . 
movement emerged in Jordan demanding reform. Among such demands has been a call for the establishment of a constitutional court. To appease the popular sentiments, a set of constitutional amendments were introduced and provided for the establishment of a constitutional court. ${ }^{2}$ Hence, the Constitutional Court of Jordan came into existence in 2012, and constitutional review became a centralized system carried out solely by the Constitutional Court (the "Court").

If one main purpose of institutionalizing a constitutional court was to entrench democratic reforms, at least in the case of Jordan, the newly created Jordanian Constitutional Court might not be suited to achieve such purpose. The Constitution limits the powers of the Court and makes it difficult for the public to access. The powers of the Court are limited to determining the constitutionality of laws and interpreting the Constitution. ${ }^{3}$ The right to request the Court to interpret a constitutional provision is exclusive to the Council of Ministers (the "Cabinet"), the Chamber of Deputies (the "Chamber") and the Senate. ${ }^{4}$ No other party has the right to such a request, including the Court itself. Furthermore, only the Cabinet, the Chamber and the Senate have the right to submit a direct challenge to the constitutionality of laws before the Court. The public, including political parties, has the right to an indirect challenge only. In cases adjudicated before courts, any party may submit a motion to challenge the constitutionality of a law. The adjudicating court, if it considers the motion substantive and serious, refers the motion to the Court of Cassation to finally decide on the seriousness of the motion and grant permission to submit the challenge to the Constitutional Court.

While hardly any constitutional court in the region possesses comprehensive powers to carry out all types of constitutional review, the Jordanian Constitutional Court namely lacks the power to review the "constitutionality" of constitutional amendments. Since the establishment of the Court, the Constitution was amended twice; 5 both amendments extended the King's powers, which effectively changed the nature of the parliamen-

2 The Constitution of The Hashemite Kingdom of Jordan of 1952, as amended in 2011. Official Gazette 5117, 1 October 2011, art. 58, 59 and 61.

3 The Constitution as amended in 2011, art. 59.

4 The Constitution as amended in 2011, art. 60.

5 The Constitution as amended in 2014. Official Gazette 5299, 1 September 2014: 5138; The Constitution as amended in 2014, Official Gazette 5396, 5 May 2016: 2573. 
tary system of government and made it closer to a presidential monarchy a hybrid of presidential and monarchic systems. ${ }^{6}$

Basically, the fact that the King monopolizes the appointment of members of the Constitutional Court leaves no room to discuss the dynamics of such appointments. Therefore, in order to understand the factors that determine the level of independence of the constitutional judges in Jordan, this chapter starts by revisiting and assessing the Jordanian constitutional and political context. Subsequently, a brief history of the constitutional review mechanism in Jordan will be followed by a description of the constitutional and legal organization of the Constitutional Court including nomination, appointment, terms and removal of members of the Constitutional Court. The chapter concludes with a discussion of the feasibility of reforming the appointment mechanism of constitutional judges in the context of political reform in Jordan.

\section{Constitutional context}

\subsection{System of government and the executive}

By virtue of the Constitution, the system of government is parliamentary with a hereditary monarchy. ${ }^{7}$ The King is the Head of the State who is immune from all liability and responsibility ${ }^{8}$ and carries out executive powers through his ministers. ${ }^{9}$ His written and verbal orders do not release the Ministers from their responsibility. ${ }^{10}$ The King exercises his powers by royal decrees countersigned by the Prime Minister and the Minister, or Ministers, concerned with the subject matter of the decree. The King expresses his consent by placing his signature above the signatures of the Prime Minister and the Ministers. ${ }^{11}$

The King appoints the Prime Minister and Ministers and dismisses them or accepts their resignations. He issues orders for holding elections of the Chamber and he appoints members of the Senate. The King convenes the Parliament (Chamber and Senate) and adjourns or prorogues it. $\mathrm{He}$

$6 \mathrm{http} / /$ constitutionnet.org/news/jordans-2016-constitutional-amendments-return-a bsolute-monarchy, accessed on March 19, 2019.

7 The Constitution, art. 1.

8 The Constitution, art. 30.

9 The Constitution, art. 26.

10 The Constitution, art. 49.

11 The Constitution, art. 40. 
may dissolve the Chamber or the Senate, and relieve any Senator of his/her membership in the Senate. The King's powers also include ratifying laws upon their adoption by the Parliament. The King is the supreme commander of the armed forces. ${ }^{12}$ Accordingly, he declares war, concludes peace and ratifies treaties and agreements. He also creates and confers civil and military ranks, medals and honorific titles, and currency is minted in his name. He has the right to grant a special pardon, commute any sentence and confirm a death sentence.

The Cabinet is responsible for administering internal and external affairs of the state, ${ }^{13}$ and collectively accountable to the House of Representatives, the elected Chamber of the legislature, for the public policy of the state and for the affairs of their ministries.

According to constitutional jurists, who are very few in Jordan, the Jordanian Constitution borrowed significantly from the 1921 Belgian Constitution, which in turn had borrowed from British constitutional customs. ${ }^{14}$ The powers granted to the King by the Constitution of 1952 seem to be identical with European constitutional monarchies, where the King acts as the Head of the State but does not rule.

\subsection{The legislative}

Members of the Senate are appointed by virtue of a royal decree and usually include the conservative class of present and former prime ministers and ministers, senior retired government officials and military officers, in addition to tribal leaders and businesspersons. The members of the House of Representatives are elected by secret ballot in a general direct election for a term of four years. The House of Representatives votes for confidence in cabinets upon their formation. It has the right to address questions to the Prime Minister and Ministers. In addition, the House of Representatives may vote for no confidence against the entire cabinet or any of its Ministers at any time.

Although the Constitution guarantees the right for establishing political parties as part of the constitutional fundamental rights, political parties are not a major player in the parliamentarian life.

12 The Constitution, art. 32.

13 The Constitution, art. 45.

14 Mohamad Al Hamoury, The Rights and Freedoms of the Whims of Politics and the Obligations of the Constitution: The Case of Jordan: 192-193. 


\subsection{The judiciary}

The Judiciary is the third branch of power and is vested in the courts. The Judiciary is independent and judgments are pronounced in the name of the King. ${ }^{15}$ The Constitution upholds the principle of the independence of judges by stating that they are independent and their judgments are subject to no authority other than that of the law. ${ }^{16}$ The Constitution further states that litigation is available to all by declaring that courts shall be open to all, hearings shall be public, and courts shall be free from any interference in their affairs. ${ }^{17}$ Courts are divided into three categories: regular courts, religious courts and special courts. The regular courts have jurisdiction over all persons, including the government, in civil, criminal and administrative matters. The Judicial Council, which oversees regular courts, has the exclusive right to appoint judges and is responsible for all of their affairs. ${ }^{18}$ The Judicial Council is presided over by the Head of the Court of Cassation, who is appointed and dismissed by a royal decree. All members of the Judicial Council are judges, except for one who is the Undersecretary of the Ministry of Justice. ${ }^{19}$

\subsection{Recent amendments}

Since its promulgation in 1952, the Constitution has been amended a number of times. Disappointingly, most of these amendments were to give the King wider authority at the expense of the Parliament, weakening its ability to play its legislative and oversight roles. The two major amendments that concern this study took place in 2011 and 2016. The 2011 Amendment provided for the establishment of a constitutional court as a standalone independent judicial entity comprised of nine members, including the Chairperson, to be appointed by the King by virtue of a royal decree. ${ }^{20}$

The 2016 Amendment represented a radical departure from the parliamentary monarchy system of government. It changed the mode of exer-

15 The Constitution, art. 27.

16 The Constitution, art. 97.

17 The Constitution, art. 101.

18 The Constitution, art. 98.

19 The Independence of Judiciary Law, as amended no. 29 for the year 2014. Official Gazette 5308, 16 October 2014: 6001.

20 The constitution as amended in 2011, art. 58. Official Gazette 5117, 1 October: 4452. 
cising royal powers. The King, who is immune from any liability and responsibility, now exercises direct executive powers in isolation from his Ministers.

Before such amendment, the Constitution provided that the King exercises the powers vested in him by royal decrees, which must be countersigned by the Prime Minister and the Minister concerned. The Constitution was amended to give the King the sole power, without any countersignature by the Prime Minister or concerned Minister, to select the Crown Prince, appoint the Regent, appoint and dismiss the Speaker and members of the Senate, appoint and accept the resignations of the Chairperson and members of the Constitutional Court, appoint and accept the resignation of the Head of the Judicial Council, appoint and dismiss the commander of the army, and the heads of Intelligence and the Gendarmerie. ${ }^{21}$

Fundamentally, these latest amendments constitutionalized the dominant powers that the King exercises on the ground, and formalized the absolute monarchy by virtue of a constitutional provision, which concentrated the power in a King who is neither legally nor politically accountable.

\section{Political context}

The constitutional text is in many ways far from the political reality in Jordan. Predictably, the consolidation of political powers in the hands of the King obstructs the democratic process and the transition of power. In such a political system, the only player is the King who has a strong presence and actual political power, with a Cabinet bearing the political and legal responsibility on the King's behalf.

\subsection{An unaccountable monarch}

In reality, the King exercises extensive governmental powers in a manner that disables the checks and balances in place within this theoretical constitutional framework. In addition to his direct control on the military and security apparatuses, the King appoints and dismisses Cabinet without providing justification. The appointment and dismissal of Cabinet is not

21 The constitution as amended in 2016, art. 40. Official Gazette 5396, 5 May 2016: 2573. 
the result of parliamentary elections through which political parties arrive at the helm of the executive. Despite the fact that Ministers are subject to means of constitutional accountability, the King has the final word in government because he reigns and rules. Subsequently, Ministers and the Prime Minister face responsibility for actions that are not the result of their own independent decisions.

\subsection{Legislative and political parties undermined}

Although Senators are selected among those who usually keep in with the mainstream, the King may dissolve the Senate or relieve any senator of his/her membership in the Senate. ${ }^{22}$ The King issues orders for holding elections and dissolves the Chamber at his sole discretion; powers which have been extensively exercised. Further, the role of the Chamber is subverted by brazen and tacit ways of interference in parliamentary elections, and support for certain candidates by encouraging them to run and oppose other candidates. In fact, parliamentary and even municipal elections have been rigged more than once without holding anyone accountable for such an act.

Political parties were banned in Jordan from 1957 until 1990. During that period, affiliation with a political party was illegal. Although twentyseven years have elapsed since lifting the ban, political parties, whether from the right, the left or the center, were never represented in Cabinets, achieved a substantial number of seats in the Chamber, or appointed in the Senate. In other words, participation of political parties is never encouraged and they have never been integrated within the fabric of the political system.

\subsection{An undermined judiciary}

Although the Constitution explicitly recognizes the independence of the judiciary, the division of the courts into civil, religious and special courts has led to the existence of different jurisdictions, negatively impacting

22 The power to dissolve the Senate and relieve a senator of his membership did not exist at the time when the Constitution was issued, but was added in a later constitutional amendment in 1974: The Constitution as amended in 1974. Official Gazette 2523, 10 November 1974. 
the unity of the judiciary and detracting from its independence. This is due to the fact that the provisions of the Constitution that pertain to the judiciary and the courts have been undermined through the enactment of various laws. These laws have dispersed judicial jurisdiction among a large number of regular, religious and special courts with different mandates. Furthermore, the establishment of special courts that are not under the jurisdiction of the judiciary, and the appointment and direction of judges by the executive power, violate the principle of separation of powers. There is no doubt that the greatest impact has been in weakening the control of the judiciary over the executive and exempting the military and security apparatuses from judicial control. The State Security Court is one of the most important examples of the special courts that lack independence. The Prime Minister constitutes the court, appoints judges and in some cases sets its mandate. In addition, some laws have created a system to combat corruption exercising judicial powers.

\section{History of constitutional review}

When the popular movement chanted in the streets demanding a constitutional court in Jordan, most of the public did not realize that there was an existing, albeit compromised, system of constitutional review in place.

\subsection{The High Tribunal}

Prior to the constitutional amendment of 2011, which created the Constitutional Court, the constitutional review and the interpretation of the Constitution were dealt with separately. The Constitution provided that a High Tribunal is to be constituted and to have the right to interpret the provisions of the Constitution upon the request of the Cabinet, the Senate or the Chamber. The High Tribunal was composed of the Speaker of the Senate as president, three Senate members to be selected by ballot, as well as five members to be selected from amongst the judges of the Court of Cassation. The High Tribunal had also the capacity of a special court to try ministers for offences attributed to them in the course of their ministerial duties. $^{23}$ 
Before a constitutional amendment that took place in 1958, the President of the Court of Cassation used to chair the High Tribunal. The amendment made the Speaker of the Senate the President of the High Tribunal. This action eliminated the High Tribunal's judicial identity and it became more political.

Besides, at the times when the Constitution provided for the composition of the High Tribunal - which included three members of the Senate - Senators were immune from dismissal during their tenure, and the King had no power to dissolve the Senate before the end of its term. A constitutional amendment took place in 1974 to give the King the power to dissolve the Senate and relieve any senator of his/her membership. Not surprisingly, this power attributed to the King, compromised the immunity and independence of Senators both in their capacities as members of the Senate and as Members of the Constitutional Court. Moreover, dissolving the Senate would automatically lead to paralyzing the High Tribunal due to the absence of its Senator members.

\subsection{Diffused constitutional review}

The power to determine the constitutionality of laws was granted to all regular judges in Jordan by default. This power was not written in the Constitution or any other law, but based on the general rule of hierarchy of laws, or legitimacy of laws; a law shall not contradict the constitution and a regulation shall not contradict the law. Judges exercised this power by refraining from applying a law if they determined that it contradicted the Constitution, but they had no power to repeal a law.

Thus, within limits, constitutional review of laws existed in Jordan prior to establishing the Constitutional Court. However, the current general understanding in Jordan is that the establishment of the Constitutional Court terminated the power of the judiciary to decide on the constitutionality of laws and regulations, and confined such control to the Constitutional Court.

Regular judges, who comprised the majority of the previous two constitutional review bodies, used to have a relatively high level of independence. Even members of the Senate, who were part of the High Tribunal, benefitted at that time of a high level of protection, and thus from removal. 


\subsection{The Judicial Council}

All regular judges, except for the President of the Court of Cassation, are appointed, promoted, disciplined, transferred and dismissed by decisions of the Judicial Council. ${ }^{24}$ The Judicial Council takes decisions by voting and its deliberations are confidential. ${ }^{25}$ The Independence of Judiciary Law provides for criteria for the appointment and nomination of judges. Generally, the Judicial Council forms a committee composed of senior judges to carry out a contest for the applicants. After running background checks for the successful applicants, the Judicial Council appoints them with a trial period of three years. Graduates of the Judicial Institute are exempted from such exams, and judges of higher courts reach their posts through promotion. The Judicial Council also has the right to appoint experienced lawyers in any court, including the Court of Cassation. Removal of judges must be through a disciplinary board and by virtue of a decision of the Judicial Council.

Theoretically, the influence of the executive on the appointment and nomination of judges is minimal. Other than the President of the Judicial Council, who is appointed solely by the King, the only executive member of the council is the Undersecretary of the Ministry of Justice. In reality, the executive would always have a word in judicial appointments through the Minister of Justice.

\section{The Constitutional Court}

\subsection{Mode of nomination and appointment}

The amended Constitution of 2011 provides for the establishment of a constitutional court, by virtue of a law, as an independent and separate judicial body. The Constitutional Court is composed of a minimum of nine members (the "Member" or "Members"), including the chairperson, appointed by the King for a nonrenewable six years term. ${ }^{26}$

According to the Constitution, in order to be nominated as a member of the Court, a person must ${ }^{27}$ : (i) be a Jordanian who does not hold any

24 Independence of Judiciary Law, art. 6.

25 Independence of Judiciary Law, art. 7.

26 The Constitution, art. 58.

27 The Constitution, art. 61. 
other nationality; (ii) have reached fifty years of age; and (iii) have served as a judge in the Court of Cassation and the High Court of Justice, ${ }^{28}$ a university lecturer of law with a professorship degree, or a lawyer with a minimum practice of fifteen years. The relevant provision of the Constitution then adds that the Member must be "one of the specialists" who meet the conditions of membership in the Senate.

The Constitutional Court Law $^{29}$ that was issued in 2012 following the constitutional amendments of 2011 reiterated the first three of the above nomination criteria, while this time requiring that only one member be a "specialist" who meets the conditions of membership in the Senate. ${ }^{30}$

Although the Constitution provides that certain Members must have a judicial background, it neither specifies their number nor states if they should form the majority of the Members. The other types of Members that can be appointed to the Court (lawyers and law professors) must have a legal background, except for the "specialist" Member who should meet the conditions of membership in the Senate. As for the latter, it is not clear what the word "specialist" means, but it is clear that such Member is not required to come from a legal background. It appears that the condition for filling this seat is left open for candidates with political affiliations and agenda that keep with the mainstream. The Constitution and the law are silent on whether the "specialist" member is eligible to chair the Court. This means that the Court could be presided over by a person without legal background, let alone being of a high level of legal expertise.

In practice, this is exactly how the provision was implemented in the first appointment of the first Members of the Court in 2012. One of the Members was a former Senator with no legal qualifications. When this Member passed away a few years later, ${ }^{31}$ he was replaced with another former Senator with a non-legal background. ${ }^{32}$

Other than the eligibility criteria for nomination mandated by the Constitution and reiterated in the law, there is no transparent criterion that governs the nomination of Members. The decision-making mechanism

28 This used to be the name of the High Administrative Court in Jordan before the constitutional amendments of 2011.

29 The Constitutional Court Law no. 15 for the Year 2012, Official Gazette 5161, 7 June 2012: 2519. See also http://www.cco.gov.jo/Portals/0/ConstitutionalCourtLaw.pdf

30 Constitutional Court Law, art. 6.

31 Marwan Dudin. http://www.cco.gov.jo/en-us/Constitutional-Court/Court-Membe rs, accessed on October 13, 2017.

32 Mohammad Dwaib. http://www.cco.gov.jo/en-us/Constitutional-Court/Court-Me mbers, accessed on October 13, 2017. 
in the Royal Palace is unknown to the public and is not regulated in legislation. Prior to the latest constitutional amendment that dispensed with the countersignature of the ministers on royal decrees, it was assumed that decisions are made within the cabinet. This is not clear anymore.

There are some indications, however, that certain non-transparent criteria are considered in the selection of Members of the Court. On 19 October 2016, news came out announcing a royal decree appointing four new Members to the Constitutional Court. ${ }^{33}$ Apparently, after the issuance of the decree, it was discovered that one of the new appointees had a dual nationality, which violates the constitutional conditions of appointment in the Court. A new decree was issued the second day replacing him with a new member. ${ }^{34}$ This incident revealed two issues: the first is that the process of nomination is injudicious and that the due background check of nominees is not well observed; and the second issue is that both appointees were Christians, which is indicative that the nomination process in the royal palace takes religious affiliation into consideration.

The other serious threat to the Court's independence in the nomination process is the loose standard in defining the number of Members of the Court. The Constitution requires that the Court be constituted of nine Members "at least". This leaves the door open to the executive to manipulate the composition of the Court and add judges to the bench to ensure that a majority will always rule in its favor. 35

The mode of nomination and appointment of Members embodies a major threat to the Court's independence; an appointment dominated by the executive. The appointing authority is not an elected one, but rather an executive who is neither legally nor politically accountable. A judge, who is solely selected by the executive without participation of any other political actor, stands little chance of being able to act independently. ${ }^{36}$

33 Ammon News Agency. http://www.ammonnews.net/article/285875, last modified on October 19, 2016, accessed October 13, 2017.

34 Ammon News Agency. http://www.ammonnews.net/article/286033, last modified on October 20, 2017, accessed October, 132017.

35 Choudhry, Sujit, and Katherine Glenn Bass, Constitutional Courts after the Arab Spring: Appointment Mechanisms and Relative Judicial Independence. New York: IDEA and Center for Constitutional Transitions at NYU Law 2014: 30.

Constitutional Courts after the Arab Spring: 29. 


\subsection{Term and removal}

According to the Court's Law, the term of the Member expires in the event of death or resignation that becomes effective upon its acceptance by the King. The King has the right to remove a Member upon the recommendation of six other Members of the Court in the following circumstances:

1. Ceasing to meet any of the conditions of membership;

2. If the Members of the Court grant consent to prosecute a Member for a criminal act or a criminal complaint relating to the duties and activities entrusted to such Member;

3. Health issues that prevent a Member from doing his/her job; or

4. Loss of civil capacity.

If the number of Court Members becomes less than nine, due to the removal of a Member or expiry of membership, the King appoints a replacement Member for the remaining term of the departing Member. ${ }^{37}$

No third party monitors the work of the Court or the Members. The Constitution provides that the judgments of the Court are issued in the name of the King and are final and binding to all authorities and to the public. ${ }^{38}$ While this is not a unique situation in constitutional courts, judgments of the Jordanian Constitutional Court are by the above-explained structures and constellations suited to be unduly influenced, considering the state of independence of the court and mode of appointment of judges.

\section{Conclusion}

According to the Constitutional Court's website, since its establishment in 2012, the Court issued 15 interpreting decisions and 28 rulings. ${ }^{39}$ A quick look at the decisions and rulings shows that most of the issues adjudicated by the Court were not very controversial. This may be due to the fact that constitutionalism is not a major part of the Jordanian legal and political mindset. The constitutionalized monopolization of power by the King left no room for the natural political actors to be part of the constitutional and political scene. The Constitution narrowed the path to the Court and

37 Law of Constitutional Court, art. 22.

38 The Constitution, art. 59/1.

39 http://www.cco.gov.jo/en-us/Documents-of-the-Court/The-Court-in-Numbers, accessed on March 19, 2019. 
deprived most of the important political players from directly accessing the Court in an effective way.

Ironically, the Constitution limits the right to directly challenge the constitutionality of laws to entities authorized to draft and approve such laws: namely, the Cabinet, which drafts bills, and the Parliament, which passes the laws. In this way, ordinary citizens, political parties and civil society organizations are deprived of the ability to directly challenge laws before the Court, even though the laws directly affect these entities' interests. The Court itself also lacks any autonomous authority to extend its control to any text or law that it deems unconstitutional. Even where the amendment of the constitution was concerned, the Court stood watching as its members were being appointed in accordance with an exclusive power.

Reforming the Constitutional Court requires the reform of the political system first. In a system where an unaccountable executive undermines all the different actors, including political parties, the participation of such actors in the appointment of constitutional judges will not lead to any meaningful change. 